\title{
Brief History of Department of Urban and Housing Development: Focal Institution for Housing Sector in Myanmar
}

\author{
Myint Naing \\ Department of Urban and Housing Development, Ministry of Construction, Nay Pyi Taw, Myanmar \\ Email: myintnaing.duhd@gmail.com
}

How to cite this paper: Naing, M. (2021). Brief History of Department of Urban and Housing Development: Focal Institution for Housing Sector in Myanmar. Current Urban Studies, 9, 730-743.

https://doi.org/10.4236/cus.2021.94043

Received: September 23, 2021

Accepted: December 5, 2021

Published: December 8, 2021

Copyright ( 2021 by author(s) and Scientific Research Publishing Inc. This work is licensed under the Creative Commons Attribution International License (CC BY 4.0).

http://creativecommons.org/licenses/by/4.0/ (c) (i) Open Access

\begin{abstract}
The housing deficit in the urban area has become a global problem especially in developing countries like Myanmar, and many countries have been concerned about addressing the challenge of providing adequate housing for their citizens. Unfortunately, successive governments of Myanmar after independence had not recognized and prioritized housing agenda except Parliamentary Democracy Regime (1948-1962) and at least three-quarters of the total population reside in inadequate housing nowadays. The focal institution of government is the key actor of action for housing sector development among all stakeholders in the third world. The main objective of this article is to examine the brief of governmental institutions related to the housing sector, era by era in Myanmar. Most governments and government institutions could not uplift the living standard (especially shelter conditions) and unable to fulfil the satisfaction of their people.
\end{abstract}

\section{Keywords}

Adequate Housing, Developing Countries, Housing Right, Institution, National Housing Policy-NHP

\section{Introduction}

Housing is one of the basic needs of humankind just like food and clothing, and international human rights law similarly recognizes everyone's right to an adequate standard of living, including adequate housing (UN Habitat, 2014). On $10^{\text {th }}$ December 1948, the United Nations General Assembly at its third session stated that "all governments have an obligation in the housing sector, for instance, by creating ministries of housing or agencies that write the housing poli- 
cies, enact the programs, plan the projects, and allocate the funds" (Ikhlas \& Shiki, 2020).

The concept of "institution" has become more prominent in recent years, and it reflects an increasing awareness of the role of the institution in the functioning of market or non-market economies (Meramveliotakis, 2018). Furthermore, institutional economists always used the role of the institution as a metaphor as one of the basic factors of production such as land, labor and capital. Politicians, economists and businessmen especially from the third world, recognize to converge to the fundamental idea that the right institutional framework constitutes a sine qua non condition in order to enhance economic growth and promote development.

Like other developing countries, housing poverty has become a noticeable issue of urban and rural housing in Myanmar. With low economic growth and high poverty rate, the majority of housing is inadequate for Myanmar people. According to the 2014 Myanmar population and housing census, only $11.28 \%$ of the housing stock was standard housing, the rest were sub-standard (mainly organic housing/traditional housing) and temporary shelters such as huts. With regard to urban housing, only a quarter of housing stock was formal housing, half was informal and the rest was mere temporary shelters (Naing \& Nitivattananon, 2020a).

Under the administrative reform process in 2013, the Department of Urban and Housing Development (DUHD) as the focal governmental institution, indicated the root causes of immature status in the housing sector which are the underdeveloped nation with an agrarian-based economy, the low population density combined with a huge land area, a greater ratio of rural to urban population ratio (70:30), an abundance of natural building materials for informal housing and incapacity of the private sector role in the housing sector (Naing \& Nitivattananon, 2020a). Moreover, all successive governments (exception for the Parliamentary Democracy Regime (1948-1962)) had not prioritized housing as one of the important agendas of the national economic development plan.

The main objective of this paper is to examine the brief of governmental institutions related to the housing sector, era by era, in Myanmar with key topics such as the government's will and intention; policy, objectives and functions of institutions; housing conditions; and performance of institutions. It is the descriptive research with the observational method. Desktop review is mainly applied and Key Informant Interview (KII) is additionally conducted with 6 senior officials from the Department of Urban and Housing Development (DUHD). The only limitation of the article is that due to the ongoing global pandemic and political turmoil, present-day Myanmar's housing sector situation cannot be reflected.

\section{Institution and Housing}

Theories of governance (including institutional theories) universally overwhelm in diverse academic disciplines such as development studies, economics, geo- 
graphy, international relations, planning, political science, public administration, and sociology (Bevir, 2011). In the late $20^{\text {th }}$ Century, relationship of state and society (including institutions \& communities) changed significantly; government and international organizations increasingly share the activity of governing with societal actors, including private firms, non-governmental organizations and non-profit services providers.

The generic aim of institutional economists (mainly from the New Institutional Economics in the 1970's and 1980's) is to explain what institutions are, how they emerge, what purposes they serve, how they evolve and how-if at allthey should be reformed (Meramveliotakis, 2018). Likewise, historical institutionalism among the three major schools of institutionalism (other as sociological institutionalism and political institutionalism) commonly seek explanations that are configurational and implicate a conjunction of institutions, process, and events (Amenta \& Ramsey, 2010).

The role of governmental institution is major not only the housing provision but also both of urban development and the growth of related industries up and down stream of housing sector (Malik, Roosli, Tariq, \& Yusof, 2020). Jerkins and Smith mentioned that the government, market and civil society must balance their mutual roles and activities to support the effective provision of equitable housing market (Jerkins \& Smith, 2001). At $10^{\text {th }}$ December, 1948, the United Nation General Assembly at its third session, stated that "all governments have an obligation in the housing sector, for instance, by creating ministries of housing or agencies that write the housing policies, enact the programs, plan the projects, and allocate the funds" (Ikhlas \& Shiki, 2020).

Hence, the World Bank recommended that "Develop a policy and institutional framework" is one of the key seven instruments of "Enabling Approach" as the current global housing policy paradigm (The World Bank, 1993). Universally, governmental institutions related housing can be transformed time by time or era by era in accordance with its respective government's political will, development ideologies, socioeconomic policies, general political and socioeconomic situation and peculiarities of historical background. Currently, the governments of the third world (like as Iran, Pakistan, and Nigeria and so on) pursue to reform and strengthen their institutions related housing to reach their national goal (Nagy, 2006; Bamidele, 2019; Malik, Roosli, Tariq, \& Yusof, 2020). As the lessons learnt from Latin America, most countries had reinforced the institutional capacity to deal with housing issues, including central government ministries, government-run housing banks and central and local housing corporations in different combinations after 1970s (Rojas, 2018).

\section{Historical Institutional Transformations of Housing Sector in Myanmar}

Theoretically, the governance approach is focused on establishing societal goals and then mobilizing the resources necessary to reach those goals (Bevir, 2011). 
Housing is generally preferred one of the prioritized social agendas after health, education, and the welfare for venerable social groups (such as children, elderly persons, disable persons, women, and economic weakness group and poor). Unfortunately, housing sector was not prioritized agenda in history of housing development in Myanmar (except the Parliament Democracy Regime with strong government will).

The first institution related housing and urban sector in Myanmar was Rangoon Development Trust (RDT) which founded in 1921, and it was consecutively transformed and restructured era by era under political changes. Although, the foundation of RDT celebrated its centenary in 2021, housing sector of Myanmar is still immature and adequate housing is out of the hand of majority of Myanmar people. Along the successive government rulings, the most of governmentterms could not fulfil their social commitment of housing for public and majority of public still reside inadequate housing with socio-economic losses especially in urban area.

\subsection{Rangoon Development Trust (RDT)}

Rangoon Development Trust (RDT) was the first government institution for housing sector, founded in $1^{\text {st }}$ February, 1921 by British Colonial Government in Burma (current name as Myanmar) (RDT, 1941). It was requested by two Presidents of Rangoon Municipality (Mr. Laurie in 1908 and Mr. Gavin Scott in 1913), and was organized as an example from Bombay Improvement Trust and Calcutta Improvement Board. The statement of main objective was that "provide to the improvement and expansion of the City of Rangoon and for the development of certain areas in and around the City with the object of securing proper sanitary conditions, amenity and convenience to the persons living in such area" (RDT, 1941).

The layout of new Rangoon (Symmetrical Chessboard Plan) was erected in 1853 by Lieutenant A. Fraser of the Bengal Engineers in line with European modern urban planning, although Rangoon (current name as Yangon) was the small principal port before Second Anglo-Burman War (1852) Under the Myanmar Kingdoms (Pearn, 1939). It was intended not only port for international maritime transport but also colonial administration center of Myanmar. Firstly, the whole urban governance (including shelter agenda) was only under the control of the Town Magistrate. In 1874, the urban governance system was legally extended for the Municipal services and British appointed a full-time official Municipal President in 1890 for both the municipal services and the administration of town land especially urban expansion.

Without British ruler's subsidies for colonial city development as their policy, Rangoon Municipal had faced budget deficit (the mortgage debt) for town land management, because of "incurring lavish expenditure on reclamation and equipment with any attempt to fix assessments which would give a reasonable return on the expenditure incurred results" (RDT, 1941). Therefore, Colonial Government initiated RDT to divide municipal services, and improvement and expan- 
sion of the City like as the Bombay Municipality and the Bombay Improvement Trust. The main two functions of RDT were to manage Government land and estates in Rangoon City and to develop the City (including the reclamation of nonGovernment land and the construction of main drain and main communications in the city). The Trustees worked through two Standing committees and six departments for reaching its objectives and functions. Institutional structure can be stated in Figure 1.

According to the recommendation of the RDT enquiry committee's report, the trust had been able to fulfil its wide functions during the two decades of their term (RDT, 1941). Origin of Fraser's plan of 1853 merely provided for a city of about 500 acres in area, it extended to an area of 13 square miles in 1976 and RDT implemented to increase approximately 30 square miles or 18,980 acres in 1941. As a successful performance by RDT, Rangoon (prime city of British Burma) would be developed in urban expansion and provided residential land for its population, reached nearly half million in 1940s which can be compared with 36 thousand population of Fraser's Plan (1853), 90 thousand in 1872, and 220 thousand in 1901 (Naing \& Nitivattananon, 2020b). Moreover, RDT could provide roads in city of total length as 332 mileages under its term which can be compared 296 mileages (1858-1920). Besides, financial performance also improved as 0.875 million rupees of opening balance on inception (1921) and 1.98 million rupees in closing balance on the $31^{\text {st }}$ March, 1940 (RDT, 1941).

\subsection{National Housing Board (NHB)}

During the first meeting of the National Housing Board (NHB) on $3^{\text {rd }}$ May, 1951, the First Prime Minister U Nu stated as the government's strong will as that "the subject of housing has been in his mind for a long time, housing program would raise the morale of the people a great deal and he had some enquiry made on the subject in detail during Europe visit in 1950" (NHB, 1951). The worst housing shortage of Rangoon could be seen during the decade of 1950s because of bombing by both sides of Japanese and British during the Second World War (WWII) and rapid internal migration by the worst civil war of Burma

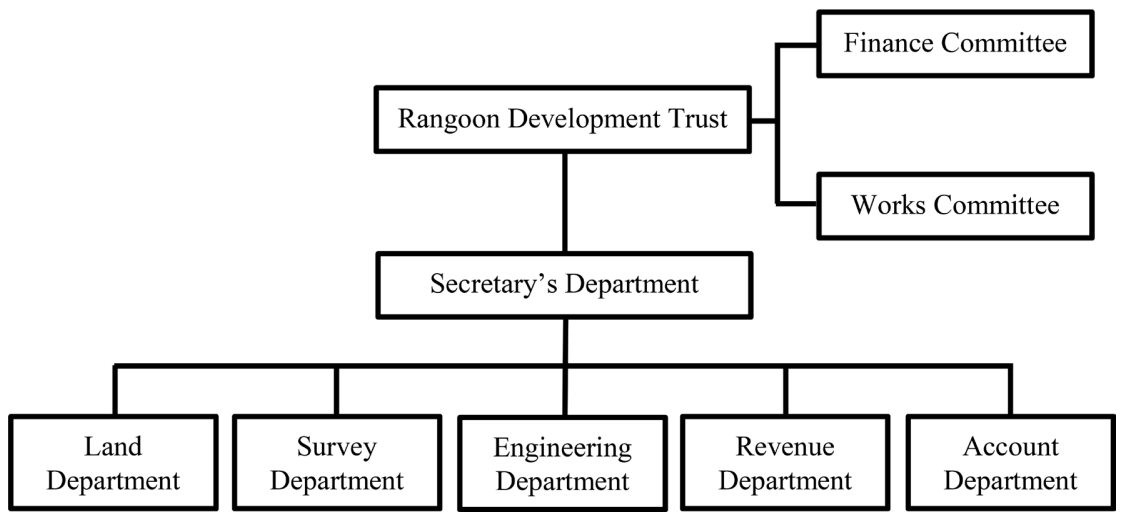

Source: Modified by author from RDT (1941).

Figure 1. Institutional Structure of RDT. 
(Naing \& Nitivattananon, 2020b). As other emerging independent countries after WWII, the first Myanmar Government with growing nationalism had strong will for state building including housing, and organized National Housing and Town and Country Development Board (abbreviated to National Housing BoardNHB) in 1951 by National Housing and Town and Country Development Board Act. Institutional structure of NHB can be stated in Figure 2.

Burma's first well known welfare plan was Pyidawtha plan (literal meaning of English as Prosperous Royal Country) which was adopted by the parliament democracy government with technical assistance from American firm Knappen Tippetts Abbett (KTA) as recommended by the United State Economic Cooperation Administration (USECA) (Than, 2013). The main concept of Pyidawtha was the Burmanized development plan based on the Burmese vision and understanding of development instead of an emulation of or a submission to, foreign ideologies and hegemony (Than, 2013). Its concept was in line with influence of Non-Aligned Movement which adopted for neutralization of Cold War Ideology.

It was a blue print of national development plan which rooted on five pillars as physique, intellect, economy, morality, and society. Famous mottos of that plan were "to create new lives" and "to bring every citizen of Burma as a brick house, a car and 800 Myanmar Kyats in salary" (Than, 2013). According to the motto, government prioritized the housing as one of most important agendas which were stated that "Social welfare expenditures must be large enough to permit education, medical and healthcare, and housing to make their proper contribution to human welfare" (KTA, 1953).

NHB was initially led by Prime Minister by self as Chairman, after that, it was ministerial organization as led by Minister for Public Work and Minister for Housing and Labor successively before seizing national power by Military in 1962. At U Nu's regime, the government tried to extend NHB as a sizeable institution for reaching their political will, RDT was merged in July (1954) and Public Work Department (PWD) was merged in October (1954) under NHB. Government strong will relate housing could be seen that they allocated initial budget of

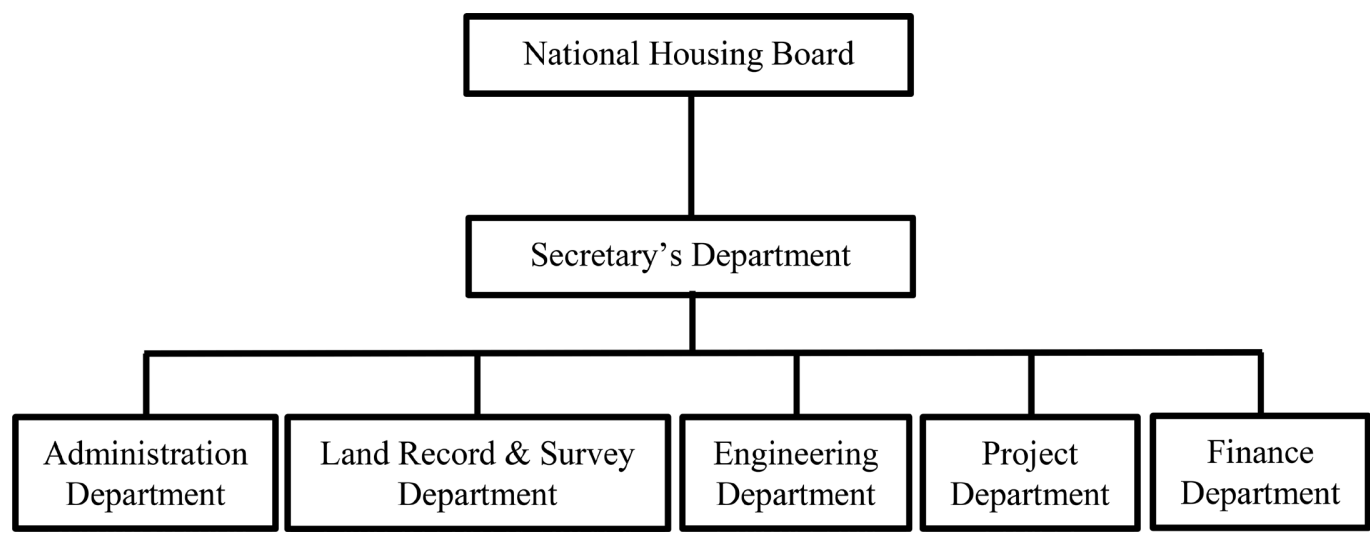

Source: Modified by author from HD (1987).

Figure 2. Institutional Structure of NHB. 
$5 \%$ of the government revenue for housing development. Mid-term goal of housing in ten years plan was intended as 240,000 permanent types of houses to be built in (1952-1962) (Warner, 1957).

During the Parliament Democracy regime, NHB provided (5254) housing units with 1197 buildings mostly public rental estates in Rangoon and other 14 townships, and transit shelters (6800) units for fire victims of Rangoon and Prome. Likewise, they constructed 24 villages as rural development pilot projects and delivered essential public amenities such as schools and hospitals at some cities. For Rangoon as a capital city, NHB tackled for housing development such as the scheme of land readjustments (mainly land areas razed by fire) and the extension Rangoon boundary by swallowing 4 Rangoon Suburban Districts in 1955. The prominent effort of NHB was 3 satellite towns development for urban extension (especially for squatter resettlement scheme) as Theketa, North Okkalapa and South Okkalapa. Under the this new towns project, NHB provided total 32,866 plots (9226 plots in Thaketa, 11,923 plots in North Okkalapa and 11,717 plots in South Okkalapa) for squatter households (Naing \& Nitivattananon, 2020b).

\subsection{Institutional Transformations under Socialism}

Under the Socialist Regime (1962-1988), housing policy and plan were totally changed from the Parliament Democracy Regime by its ideology. The Government did not promote homeownership because of non-recognition of private ownership in accordance with Socialism. Therefore, they concentrate on government staff rentals who were favorable social class under its era. Moreover, housing supply by private sector was totally decreased because of adoption of nationalization and eradication for private sector (except organic housing or traditional housing by local carpenter and mason). A snapshot of 1970, urban housing situation can be stated that "while urban housing demand was 30,000 per annual, public housing was only 100 and private housing was only 400 for annual delivery all over the country especially in towns (population 10,000 and above)" by internal report of Housing Department (HD).

In 1965, the government found Public Work Corporation with combination of many Engineering departments from various Ministries (including NHB) and role of NHB was gradually reduced and transformed into grade (B) department led by Director General under socialist's new administration system. In 1972, NHB was restructured into Housing Board (HB) and changed the name into Housing Corporation during the same year. In 1973, the Government changed again into Housing Department (HD) (HD, 1989). Organization structure of HD can be stated in Figure 3.

Under this regime, housing was not the most prioritized agenda like as $\mathrm{U} N \mathrm{Nu}^{\prime}$ s regime and they had no particular National Housing Policy (NHP) as Pyidawtha Plan. General concept of housing was that "government role was only lead and guidance, public must need to try themselves on self-help basis" (HD, 1989). The 


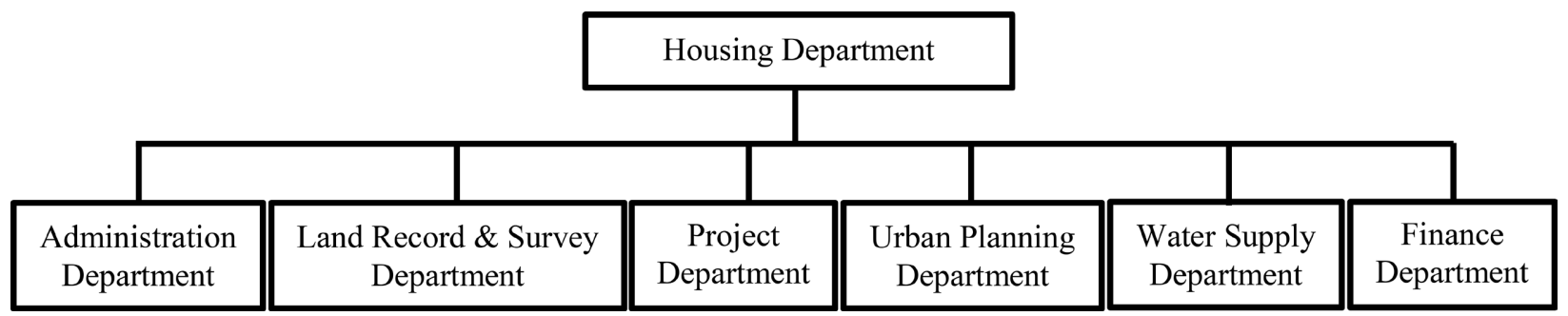

Source: Modified by author from HD (1987).

Figure 3. Institutional Structure of HD.

performances of HD during Socialist era were delivery of public rental 7,958 dwellings ( 885 buildings), collective housing 72 dwellings, and government sale housing 360 dwellings during (1962-1988). Other urban development projects were the No (1) Pilot Farming Village project in Hlegu Township, land readjustment projects for squatter pockets (9290 plots), deteriorated building reconstruction projects, and urban infrastructure projects as road constructions and water supply in Rangoon. Significant scheme of public housing under socialism was nationalization of private owned apartments (usage of commercial and residential) about three thousand dwellings by socialist's practices during 1960's/1970's, and rent out people (especially government staffs and urban poor) as public rental housing.

\subsection{Department of Human Settlement and Housing Development (DHSHD)}

In 1990, General Saw Maung as Chairman of State Law and Order Restoration Council-SLORC (Leader of Military Coup) mentioned on housing that "Housing Department must not be responsible only for the public housing delivery behalf of the government such as public rental estates and government staff rental housing, it should focus on urban and rural housing development conceptual master plan covering the whole country as macro-level" (SLORC, 1990). The military government founded and upgraded City of Yangon Development Committee (Name change from Rangoon to Yangon, Burma to Myanmar in 1989 under SLORC) to handle the all responsibilities of urban development of Yangon with enacting City of Yangon Development Committee Law (1990). They restructured from HD (Grade-B) to Department of Human Settlement and Housing Development-DHSHD (Grade-A Department) including 5 State and Region Branch Offices. Institutional structure of DHSHD can be stated in Figure 4.

Under the military ruling, the government had no particular NHP, programs and plans were only ad-hoc basic because they did not have long-term policy and strategic plan by interim government practices. But, DHSHD had exercised many housing and urban development projects mainly in Yangon for promoting the political image of military's councils. The government wanted to show the global community for their achievements like as peace and stability of society, 


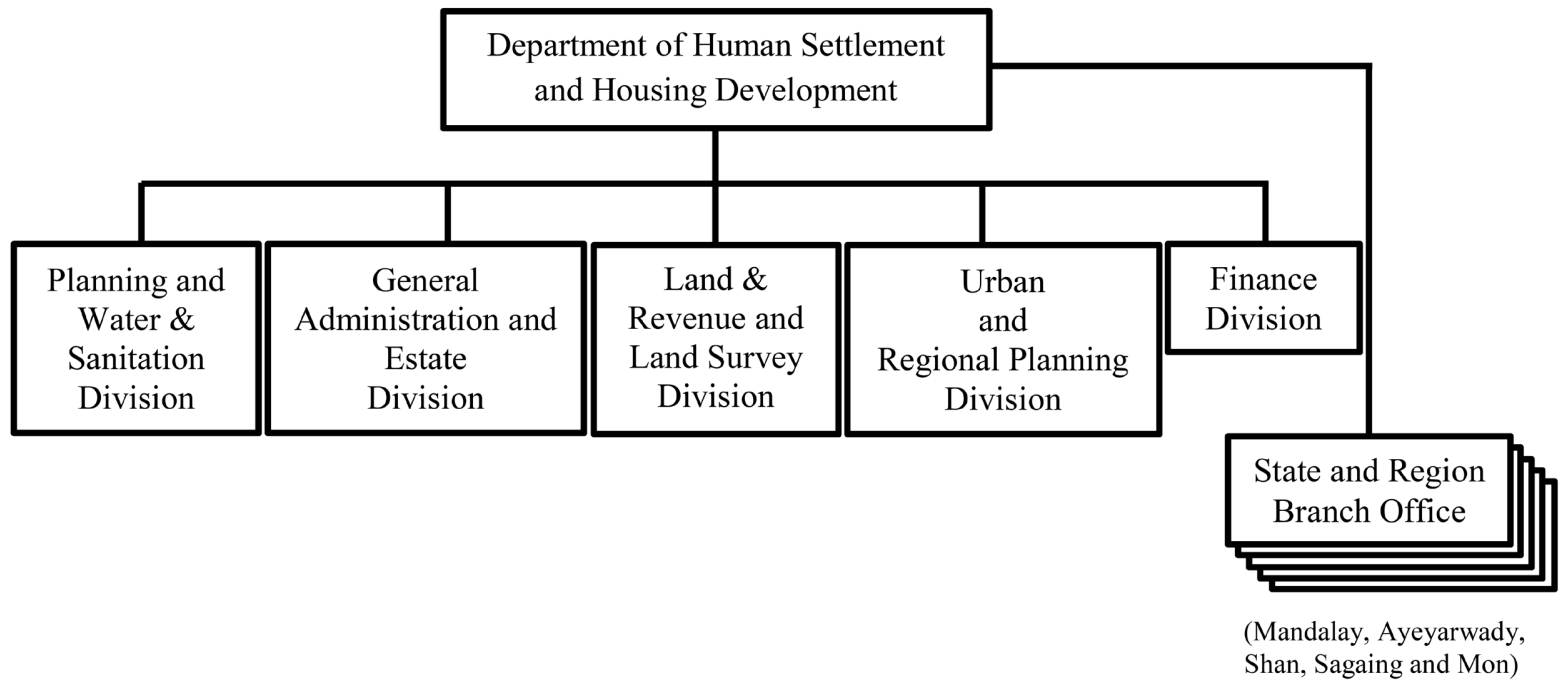

Source: Modified by author from DUHD (2013).

Figure 4. Institutional Structure of DHSHD.

economic and social development, and aesthetic improvement of urban landscape mainly in Yangon as a Capital City. With respect to financial policy for housing, it was "non-profit and non-lost" policy, government budget generally could not subsidize and most of expenditures especially site and services, and public infrastructures were incurred from profits of commercial real estate projects of government land as "cross subsidies practices".

Noticeable results of housing and urban sector development by DHSHD were erecting 6 new satellite towns for Rangoon expansion, constructing the 29 industrial zones, providing site and services scheme with about 230,000 land plots (for government staffs, urban poor and squatters), 34 land readjustment schemes of squatter spots (Hut to Apartment) (6654 dwellings), urban rejuvenation with 74 commercial building projects (preparation for ASEAN chairmanship of Myanmar), and about 51,649 housing dwellings for low and medium income group. Moreover, many physical, economic and social amenities were delivered such as roads, markets and shopping places, schools and so on.

\subsection{Department of Urban and Housing Development (DUHD)}

In 2011, Myanmar had undergone a dramatic transition from military ruling to the elected government and this change has surprised the global community with so called democratization (Naing \& Nitivattananon, 2020a). The elected government committed to transform democracy in politics and market-oriented in economics. They announced to execute the four serial reforms as the political reform, the economic reform, the administrative reform and the private sector reform consecutively. Unfortunately, housing and urban development was excluded like as sectoral strategies for dynamic and inclusive growth including rural development (ADB, 2014).

Although $40 \%$ of the countries all over the world enshrine the housing right in 
their respective constitutions explicitly, Constitution of the Republic of the Union of Myanmar 2008 does not confer to their citizen as housing right for the constitutional right. In article 36(c), that is stated only as basic principle as "The Union shall; strive to improve the living standards of the people and development of investments" (MoI, 2008). Another matter for housing has become arguably enactments in this constitution as Schedule one (Union Legislative List refer to section 96) serial number 8 contain in "Transport, Communication and Construction Sector", serial number $8(\mathrm{n})$ is "Television, satellite communication, transmission and reception, and similar means of communication and housing and buildings" and Schedule two (Region or State Legislative List refer to section 188) serial 6 contain in "Transport, Communication and Construction Sector", serial $6(\mathrm{~h})$ is "housings and buildings having the right to be undertaken in the Region or State in accord with the law enacted by the Union".

While all political leaders under the two democratic government terms (20112021) mentioned as nation must be built as federal democracy state, the backbone of constitution is for unitary government. Therefore, boundary of role and responsibility of housing and urban sector are not definitely clear between Union Ministry and Region and State Government like as gap and lapping roles of government authorities at central, regional and local levels. In accordance with the administrative reform, DHSHD was restructured to Department of Urban and Housing Development (DUHD) in $1^{\text {st }}$ April, 2015 as the transformation of regularity role all over the country. It expended to 14 branch offices for Region and State Governments, and 5 Self-Administered Region and Zones. New organization of DUHD can be stated in Figure 5.

Under the serial reform processes of transition period, housing and urban sector had been facing challenges and difficulties on unsolved issues and agendas like the rest of other sectors. DUHD had tried to set up National Policies, and enact and amend current legal framework. With low government's will, although DUHD compiled and proposed National Urban Policy (NUP) and National

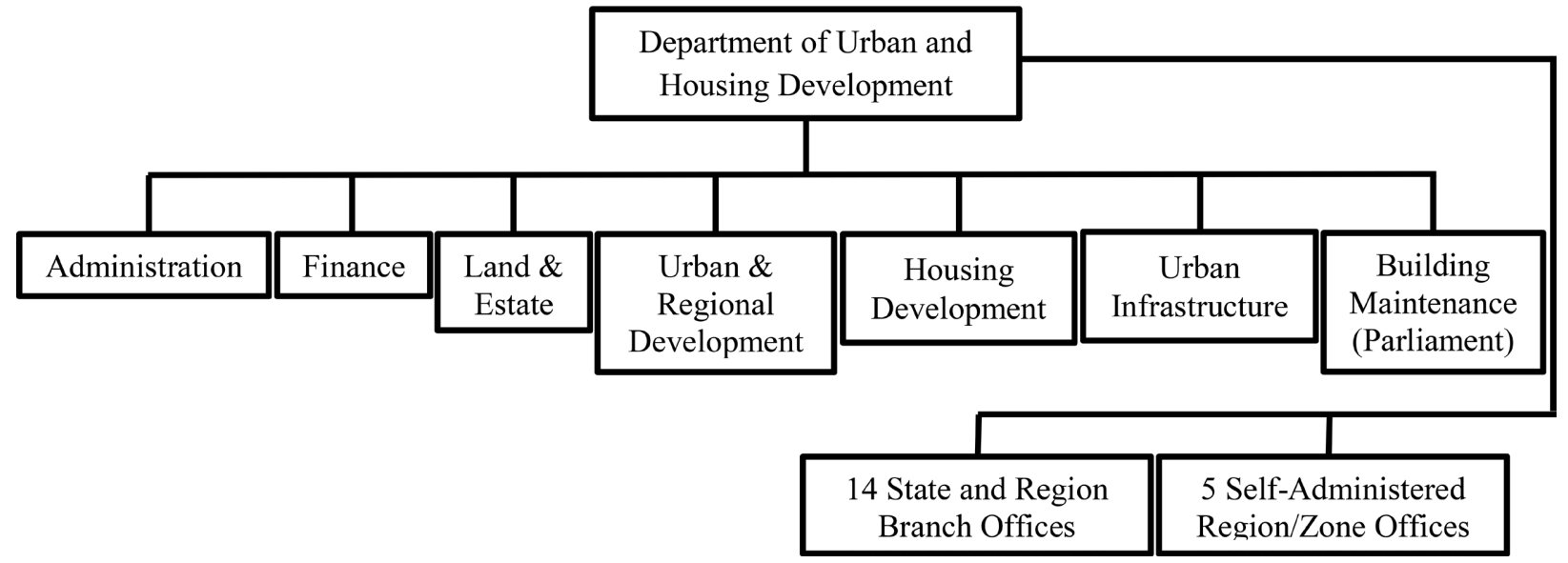

Source: Modified by author from DUHD (2016).

Figure 5. Institutional Structure of DUHD. 
Housing Policy (NHP) as the conceptual white papers, these were not officially and legally adopted by Union Governments in this period (DUHD \& UN Habitat Myanmar, 2017a; DUHD \& UN Habitat Myanmar, 2017b). Likewise, Region and State Governments did not have particular policy and strategic plans, and implemented only on ad-hoc basic approach. For instance, Yangon Region Government tried to solve squatter issue for urban poor as the prioritized agenda for Yangon Region, some regional governments focused on town plans for their selected towns, and public rental housing projects for their government staff (Naing \& Nitivattananon, 2020b).

About implementation, the two democratic governments produced 28,901 dwellings public sale housing (mainly Yangon) and 21,699 dwellings (totally 50,600 units) for government staff housing in Regions and States during this decade (20112021). Noticeably, these two central governments arranged two sizeable public rental housing schemes incidentally during the election year about two thousand project in 2015 and ten thousand project in 2020 .

\section{Performance of Consecutive Governmental Institutions Related Housing}

Majority of the Governments commonly accepted that uplifting the living standard of citizen (including housing) is one of the prioritized agendas for their political will and socioeconomic development of their nation. In accordance with urging by UN assembly, many governments assemble to found the ministry for housing (such as India, Malaysia, and Saudi Aribia and so on ), set up National Housing Policy, enact laws and regulations related housing agenda, set up short, mid and long-term plans, allocate sufficient budget, prepare sizable projects and deliver adequate shelter for their citizen. Unfortunately, housing is not prioritized agenda of all successive governments in Myanmar after independence (except the Parliament Democracy era).

Likewise, consecutive governmental institutions of housing and urban were not ministerial level institutions, only the role of the department led by Director General. Furthermore, there were only one National Housing Policy-NHP (Pyidawtha Plan) in 1950's in Myanmar and other government terms had implemented on ad-hoc practices without particular NHP. Only under the Parliament Democracy regimes, Myanmar government allocated sufficient budget as $5 \%$ of government's revenue as the rule of thumb, and other governments had provided annually a few budget as lower than $1 \%$. As the results, direct subsidies of DUHD for residential agenda cannot fulfil insufficient population of beneficiary as less than $1 \%$ of total population (direct subsidies) and less than $5 \%$ of total population (indirect subsidies) up to nowadays.

Therefore, housing conditions are not inadequate both in urban and rural housing for people along all four political eras even under the Parliament Democracy's era because of war torn nation, and focal institutions could not fulfil the housing needs and satisfaction of public. If there is no serious action taken 
by government with regards to housing sector development in near future, housing conditions especially urban areas (Major cities and some secondary cities) will be worse than conditions of late $20^{\text {th }}$ Century, and housing poverty will become unalleviated issue of urban poor for many decades.

\section{Conclusion}

Although some governments attempt to pursue the housing sector development, the housing deficit is a global problem (especially in urban areas) and most countries are concerned about addressing the challenge of providing adequate housing for their citizens especially in current urbanized regions as Latin America, Asia and Africa. Similarly, the current housing conditions of Myanmar are inadequate for the majority of citizens like other developing countries.

Moreover, the housing situation especially urban housing in major cities (especially Yangon and Mandalay) has been facing immense shortage and growth of informal housing (especially slum and squatter formation and informal rental practices) by the fueling of rapid urbanization like other urbanized cities of the developing countries in Asia. Besides, it is recommended that Myanmar should consider global climate change as a challengeable issue in housing resilience and disaster risk reduction because of lessons learned by previous natural and manmade disasters such as earthquakes, cyclones, floods and fires and so on.

Lack of government strong will, weakness of focal institution's capability and inefficiency of the private sector, adequate housing has not been reachable for the majority of citizens in Myanmar and housing poverty is a lasting and unsolved agenda for all stakeholders. Likewise, the overlapped responsibilities for urban and housing between Central Government, and Regional and State Governments have become the root cause in continuing the sustainability of housing sector development. With negligence of the World Bank's recommendation for the housing sector as "develop a policy and institutional framework" and Habitat III recommended policy for new urban agenda as "urban governance, capacity and institutional development", housing and urban issues are challengeable agenda of all stakeholders of major cities in the very near future (The World Bank, 1993; UN Habitat, 2016).

As the governmental institution is the key actor of action among all stakeholders, the Myanmar government should start on institutional restructure and strengthening as the first step for the sustainable development of housing. "Enabling Approach" is a current global housing policy paradigm, it does not provide a detailed route map to policymakers as to how to formulate policy and indicate how these principles are to be translated into concrete policy reform. Therefore, the policymakers of high authorities should pursue to enabling approach and explore the right and applicable policies and strategies and effective programmatic schemes which are based on the respective current situation in Myanmar. 


\section{Conflicts of Interest}

The author declares no conflicts of interest regarding the publication of this paper.

\section{References}

ADB (Asian Development Bank) (2014). Myanmar Unlocking the Potential Country Diagnostic Study. Asian Development Bank.

Amenta, E., \& Ramsey, K. M. (2010). Institutional Theory. In K. T. Leicht, \& J. C. Jenkins (Eds.), Handbook of Politics: State and Society in Global Perspective (pp. 15-39). Springer. https://doi.org/10.1007/978-0-387-68930-2_2

Bamidele, A. (2019). Strengthening Institutions for Housing Delivery in Nigeria. CBN EConomic and Financial Review, 57, 153-176.

Bevir, M. (2011). The SAGE Handbook of Governance. SAGE Publications Ltd.

DUHD (Department of Urban and Housing Development) \& UN Habitat (2017a). National Housing Policy White Paper. Ministry of Construction, Myanmar.

DUHD (Department of Urban and Housing Development) \& UN Habitat (2017b). National Urban Policy Framework. Ministry of Construction, Myanmar.

DUHD (Department of Urban and Housing Development) (2013). Initial Report of Framework for Socio Economic Reform (Unpublished). Department of Urban and Housing Development, Ministry of Construction, Myanmar.

DUHD (Department of Urban and Housing Development) (2016). Five Year Report (2011 2016) (Unpublished). Department of Urban and Housing Development, Ministry of Construction, Myanmar.

HD (Housing Department) (1987). 25 Years Report of Housing Department (1962-1987) (Myanmar Language). Housing Department.

HD (Housing Department) (1989). Internal Report for Transformation from RTD to HD (Myanmar Language). Housing Department.

Ikhlas, I., \& Shiki, K. (2020). The Lack of Childcare as a Housing Problem: Evaluating the Role of Rusunawa Public Rental Housing as Transitional Housing for Low-Income Families in Batam City, Indonesia. Journal of Regional Information and Development, 9, 82 93.

Jerkins, P., \& Smith, H. (2001). An Institutional Approach to Analysis of State Capacity in Housing Systems in the Developing World: Case Studies in South Africa and Costa Rica. Housing Studies, 16, 485-507. https://doi.org/10.1080/02673030120066563

KTA (Knappen Tippetts Abbett) (1953). Comprehensive Report: Economic and Engineering Development of Burma. Hazell, Watson \& Viney, Ltd.

Malik, S., Roosli, R., Tariq, F., \& Yusof, N. (2020). Policy Framework and Institutional Arrangements: Case of Affordable Housing Delivery for Low-Income Groups in Punjab, Pakistan. Housing Policy Debate, 30, 243-268. https://doi.org/10.1080/10511482.2019.1681018

Meramveliotakis, G. (2018). New Institutional Economics: A Critique of Fundamentals \& Broad Strokes towards an Alternative Theoretical Framework for the Analysis of Institutions. Asian Journal of Social Science Studies, 3, 50-64.

https://doi.org/10.20849/ajsss.v3i2.395

MoI (Ministry of Information) (2008). Constitution of the Republic of the Union of Myanmar (2008). Ministry of Information, Myanmar.

Nagy, G. (2006). Strengthening the Capacity of the Housing Sector in Iraq (pp. 3-8). UN-Ha- 
bitat Programme, Housing Finance International.

Naing, M., \& Nitivattananon, V. (2020a). Analysis of Housing Market with the Roles of Private House-Builders on the Middle-Income Group (MIG) Segment in Yangon, Myanmar. Journal of Construction in Developing Countries, 25, 83-108. https://doi.org/10.21315/jcdc2020.25.1.5

Naing, M., \& Nitivattananon, V. (2020b). Comparison of Issues and Countermeasures among Previous and Current Squatter Formations in Yangon, Myanmar. Current Urban Studies, 8, 396-416. https://doi.org/10.4236/cus.2020.83022

NHB (National Housing Board) (1951). Record of Annual Board Resolutions (1951). National Housing Board.

Pearn, B. P. (1939). A History of Rangoon. American Baptist Mission Press.

RDT (Rangoon Development Trust) (1941). Report of the Rangoon Development Trust Enquire Report. Government Printing and Stationery, Burma.

Rojas, E. (2018). No Time to Waste' in Applying the Lessons from Latin America's 50 Years of Housing Policies. Environment and Urbanization, 31, 177-192. https://doi.org/10.1177/0956247818781499

SLORC (State Law and Order Restoration Council) (1990). Meeting Minutes of SLORC Cabinet Meeting (24/90) (Unpublished). State Law and Order Restoration Council.

Than, T. (2013). The Languages of Pyidawtha and the Burmese approach to national development. South East Asia Research, 21, 636-654.

https://doi.org/10.5367/sear.2013.0177

The World Bank (1993). Housing Enabling Markets to Work. The World Bank

UN Habitat (2014). Fact Sheet No. 21. The Right to Adequate Housing. Office of the United Nations High Commissioner for Human Rights, United Nation.

UN Habitat (2016). Habitat III Policy Papers. Urban Governance, Capacity and Institutional Development. In United Nations Conference on Housing and Sustainable Urban Development (Habitat III) (p. 4). United Nations.

Warner, W. D. (1957). New Town Housing and Planning for Burma. Thesis Paper for Master in Architecture. Massachusetts Institute of Technology. 